\title{
ANALISIS FAKTOR-FAKTOR YANG MEMENGARUHI NIAT PENGGUNAAN E-MONEY MELALUI APLIKASI PEMBAYARAN BERBASIS DIGITAL MENGGUNAKAN MODEL UTAUT
}

\author{
Meilinda Dwi Anugrah ${ }^{1}$, Hermaya Ompusunggu² \\ Fakultas Ilmu Sosial dan Humaniora Universitas Putera Batam \\ Jl. Soeprapto Tembesi, Muka Kuning, Batam \\ E-mail : Meilinda.Dwi@puterabatam.ac.id \\ diterima: 13/10/2020; direvisi: 16/1/2021; diterbitkan: 26/3/2021
}

\begin{abstract}
Today's technological developments encourage the use of e-money not only on payment cards, but also through digital-based payment apps. The study aims to identify what factors influence an individual's intention to use e-money through a digital-based payment app with the UTAUT model. Data collection is done by distributing questionnaires online through google docs. The sample used in this study was 290 e-money users in Batam City. Based on the results of hypothetical testing using WrapPLS 7.0, there are five supported hypotheses, while the other two hypotheses are not supported. This research contributes to government programs to realize the digital economy in various industrial sectors, especially to provide solutions for cashless transactions in Indonesia
\end{abstract}

Keywords: UTAUT; e-money; digital-based payment applications

\section{PENDAHULUAN}

Kemajuan teknologi saat ini mengubah sistem pembayaran tradisional menjadi sistem pembayaran digital. Pengunaan layanan pembayaran berbasis aplikasi digital bergantung pada perangkat ponsel karena lebih mudah dan praktis (Nag \& Gilitwala, 2019). Perkembangan teknologi mendorong suatu inovasi baru, yaitu munculnya instrumen pembayaran secara elektonik yang diatur dalam Peraturan Bank Indonesia No. 11/12/PBI/2009 terkait dengan uang elektronik (e-money).

Digital money atau electronic money merupakan suatu unit dari uang digital yang mewakili uang nyata yang dapat digunakan sebagai media pertukaran elektronik (Lynch \& Lundquist, 1996). Melalui e-money, pengguna akan mendapatkan keuntungan yaitu metode pembayaran dengan biaya yang lebih rendah, cepat, nyaman, mudah diakses, dapat diandalkan, dan tingkat risiko yang dapat diterima (Dehghan \& Haghighi, 2015).

Perkembangan dari kemajuan teknologi mendorong penggunaan $e$ - money tidak hanya sebatas pada kartu pembayaran. Contoh dari sistem pembayaran yang berkembang saat ini adalah "near field communication system", yang mana setiap individu dapat melakukan pembayaran hanya dengan menggunakan perangkat elektronik, dompet seluler, transfer uang online, transfer dana secara elektronik, dan lainlain (Gurkaynak \& Yilmaz, 2015). Dengan demikian, e-money merupakan alat pembayaran modern yang tidak hanya menggunakan kartu, tetapi juga melalui aplikasi berbasis digital yang terkoneksi dengan rekening bank (Octabriyantiningtyas et al., 2019).

Seperti negara maju lainnya, Indonesia juga memiliki e-money melalui layanan aplikasi pembayaran berbasis digital. Diantaranya yaitu Gopay, OVO, Dana, Link Aja, Jenius, Doku Wallet, dan lain-lain. Menurut riset iPrice Group, aplikasi pembayaran berbasis digital dengan pengguna terbanyak diduduki oleh GO-PAY, OVO, Dana dan Link Aja (Devita, 2019). Setiap tahun pengguna $e$ money meningkat, namun peningkatan tersebut tidak diiringi dengan peningkatan 
Jurnal Ilmiah Ekonomi dan Bisnis

Vol. 18. No.1,Maret 2021 : 47-56

EISSN : $2442-9813$

ISSN : $1829-9822$

transaksi yang dilakukan menggunakan e-money (Octabriyantiningtyas et al., 2019). Hal ini terjadi di Indonesia, volume transaksi e-money melalui aplikasi pembayaran berbasis digital tidak begitu tinggi dibandingkan dengan transaksi via ATM transfers, debit cards, dan internet banking (Agusta et al., 2018). Jika dibandingkan dengan Kawasan ASEAN lainnya, tingkat pertumbuhan transaksi dengan pembayaran seluler di Indonesia masih tertinggal (Taufan \& Yuwono, 2019). Indonesia hanya tumbuh sekitar $47 \%$, Vietnam sebesar 61\%, Hongkong sebesar $64 \%$, Thailand sebesar $67 \%$, dan China sebesar 86\% (PWC Research, 2019).

Penelitian Gunawan, Sinaga, \& WP (2019) dan Sivathanu (2019) menggunakan model UTAUT untuk menguji faktor-faktor yang memengaruhi niat individu terhadap penggunaan e-money. Hasil penelitian menunjukkan bahwa ekspektasi kinerja, ekspektasi usaha, pengaruh sosial, kondisi pemfasilitasi, dan kecemasan menjadi faktor yang mempengaruh individu untuk menggunakan e-money.

Penelitian-penelitian sebelumnya tidak melakukan perluasan pengujian pada pengaruh tujuh konstruk model UTAUT terhadap niat individu pada penggunaaan teknologi e-money. Penelitian terbatas pada menguji empat konstruk (ekspektansi kinerja, ekspektansi usaha, pengaruh sosial, kondisi pemfasilitasi), sementara tiga konstruk lainnya tidak diuji secara lebih luas (efikasi diri, kecemasan, sikap terhadap penggunaan teknologi). Selain itu, penelitian mengenai faktor-faktor yang memengaruhi niat individu terhadap penggunaan teknologi $e$-money di Indonesia, khususnya di daerah Kepulauan belum tersedia. Oleh karena itu, penelitian ini bertujuan untuk mengidentifikasi faktor-faktor yang memengaruhi niat individu menggunakan e-money melalui aplikasi pembayaran berbasis digital dengan model UTAUT. Pengumpulan data dilakukan melalui kuesioner online kepada pengguna e-money di Kota Batam.

Penelitian ini dilakukan karena penggunaan $e$-money yang belum merata ke seluruh daerah Indonesia, khususnya kota Batam. Tingkat penggunaan $e$-money melalui aplikasi pembayaran berbasis digital hanya tumbuh sekitar $1.63 \%$ di wilayah Kepulauan Riau (BPS Indonesia, 2019). Penggunaan aplikasi masih terbatas pada aplikasi Grab yang bekerja sama dengan OVO, Gojek dengan menggunakan GO-PAY, dan aplikasi Link Aja.

Penelitian ini menggunakan tujuh konstruk model UTAUT untuk menguji variabel mana yang berpengaruh signifikan terhadap niat individu untuk menggunakan e-money. Penelitian ini berkontribusi pada program pemerintah untuk mewujudkan perekonomian digital di berbagai sektor industry. Penelitian ini juga berkontribusi bagi penyedia layanan untuk memberikan informasi terkait faktor-faktor yang memengaruhi pengguna dalam menggunakan e-money sehingga penyedia layanan aplikasi dapat memberikan kepuasan pada pengguna.

\section{TINJAUAN PUSTAKA}

Terdapat beberapa teori yang menjelaskan bagaimana teknologi tersebut diterima dan digunakan oleh pemakainya (Hartono, 2008). Teori tersebut diantaranya yaitu: teori tindakan beralasan (theory of reasoned action atau TRA), model penerimaan teknologi (technology acceptance model atau TAM), teori perilaku rencanaan (theory of planned behavior/TPB), dan lainnya. Berdasarkan teori-teori tersebut, Venkatesh et al., (2003) mengusulkan model UTAUT (Unified Theory of Acceptance and Use of Technology) sebagai alternatif dari model TAM (Keong et al. 2012). 
Ekspektansi kinerja (performance expectancy) yaitu sejauh mana setiap individu percaya jika menggunakan sistem akan meningkatkan kinerja. Terdapat lima konstruk dalam ekpektansi kinerja, yaitu: motivasi ekstrinsik (extrinsic motivation), kegunaan persepsian (perceived usefulness), kesesuaian tugas (job-fit), ekspektasi hasil (outcome expectations), dan keuntungan relative (relative advantage (Venkatesh et al., 2003). Penelitian terdahulu menyatakan ekspektasi kinerja menjadi anteseden utama dalam adopsi pembayaran berbasis digital. Selain itu, penelitian terdahulu juga menunjukkan hubungan positif antara ekspekstansi kinerja dengan niat menggunakan e-money. Sistem e-money melalui pembayaran berbasis digital memberikan kemudahan dan meningkatkan kinerja kepada konsumen untuk melakukan transaksi keuangan sehari-hari (Gunawan, Sinaga, \& WP, 2019; Sivathanu, 2019). Hipotesis pertama dalam penelitian ini adalah:

H1: ekspektansi kinerja memiliki pengaruh positif dan siginifikan terhadap niat individu dalam menggunakan $e$ money melalui aplikasi pembayaran berbasis digital.

Ekspektansi usaha (effort expectancy) yaitu tingkat kemudahan penggunaan suatu sistem. Terdapat tiga konstruk dari ekspektansi usaha, yaitu: kemudahan penggunaan persepsian (perceived ease of use), kerumitan (complexity), dan kemudahan penggunaan (ease of use) (Venkatesh et al., 2003). Ekspektansi usaha memengaruhi kepuasan dan kelanjutan pengguna untuk menggunakan suatu sistem. Jika sistem mudah digunakan, maka usaha yang dilakukan tidak begitu tinggi, dan apabila suatu sitem ternyata sulit untuk digunakan maka diperlukan usaha yang tinggi untuk menggunakannya (Hartono, 2008). Hasil penelitian terdahulu menyatakan bahwa ekspektasi usaha berpengaruh positif pada niat penggunaan aplikasi online (Tak \& Panwar, 2017). Selain itu, ekspektasi usaha secara signifikan dapat mendorong adopsi aplikasi pembayaran berbasis digital melalui seluler (Gupta \& Arora, 2020; Baishya \& Samalia, 2020). Hipotesis kedua dalam penelitian ini adalah:

$\mathrm{H} 2$ : Ekspektansi usaha memiliki pengaruh positif dan siginifikan terhadap niat individu dalam menggunakan e-money melalui aplikasi pembayaran berbasis digital.

Pengaruh sosial (social influence) yaitu sejauh mana individu mempersepsikan kepentingan yang diyakini oleh orang lain memengaruhinya untuk menggunakan sistem yang baru. Penelitian terdahulu menunjukkan bahwa pengaruh sosial merupakan faktor pendukung yang kuat dalam menjelaskan varians niat perilaku dalam menerima suatu sistem pembayaran berbasis digital. Kesediaan individu untuk menggunakan suatu sistem dipengaruhi oleh opini orang-orang disekitarnya (Junadi \& Sfenrianto, 2015; Al-Okaily et al., 2020). Hipotesis ketiga dalam penelitian ini adalah:

H3: Pengaruh sosial berpengaruh positif dan siginifikan terhadap niat individu dalam menggunakan e-money melalui aplikasi pembayaran berbasis digital.

Kondisi pemfasilitasi (facilitating conditions) yaitu kepercayaan individu bahwa infrastruktur organisasional dan teknikal tersedia untuk mendukung penggunaan sistem (Venkatesh et al., 2003). Penelitian sebelumnya menyatakan bahwa kondisi pemfasilitasi berpengaruh positif terhadap penggunaan teknologi online melalui dompet seluler (Chawla \& Joshi, 2019; Odoom \& Kosiba, 2020). Hipotesis keempat dalam penelitian ini adalah:

H4: Kondisi pemfasilitasi berpengaruh positif dan siginifikan terhadap niat 


\section{Jurnal Ilmiah Ekonomi dan Bisnis}

Vol. 18. No.1,Maret $2021: 47-56$

EISSN : $2442-9813$

ISSN : $1829-9822$

individu dalam menggunakan e-money melalui aplikasi pembayaran berbasis digital.

Efikasi diri (self efficacy) mengukur kemampuan individu dalam menggunakan suatu teknologi untuk menyelesaikan pekerjaan (Venkatesh et al., 2003). Pada penelitian ini, efikasi diri merupakan pengukuran atas penilaian kemampuan individu dalam menggunakan suatu aplikasi pembayaran digital (Yu, 2014). Penelitian terdahulu menyatakan bahwa efikasi diri berpengaruh positif dan signifikan pada penggunaan pembayaran mobile secara digital (Al-Saedi et al., 2020). Hipotesis kelima dalam penelitian ini adalah:

H5: Efikasi diri berpengaruh positif dan siginifikan terhadap niat individu dalam menggunakan e-money melalui aplikasi pembayaran berbasis digital.

Kecemasan (anxiety) merupakan aspek emosional seseorang ketika menggunakan suatu teknologi. Kecemasan didefinisikan sebagai kecemasan atau ketakutan individu dalam menggunakan komputer (Venkatesh et al., 2003). Tingkat kecemasan yang lebih tinggi pada suatu sistem akan mengarah pada sikap negatif dalam menggunakan sistem tersebut (Rana et al., 2017). Hipotesis keenam dalam penelitian ini adalah:

H6: Kecemasan berpengaruh negatif terhadap niat individu dalam menggunakan e-money melalui aplikasi pembayaran berbasis digital.

Sikap terhadap penggunaan teknologi (attitude toward using technology) yaitu keseluruhan reaksi perasaan dari individu untuk menggunakan suatu sistem (Venkatesh et al., 2003). Hasil penelitian terdahulu menyatakan bahwa sikap merupakan prediktor yang kuat dalam mempengarui niat invidu dalam menggunakan layanan aplikasi pembayaran digital (Verma et al., 2020). Selain itu, penelitian lain juga menunjukkan bahwa sikap berpengaruh positif pada penggunaan layanan aplikasi pembayaran berbasis digital (Ting et al., 2016; Patil et al., 2020). Hipotesis ketujuh dalam penelitian ini adalah:

H7: Sikap terhadap penggunaan teknologi memiliki pengaruh positif terhadap niat individu dalam menggunakan e-money melalui aplikasi pembayaran berbasis digital.

Model penelitian ini adalah sebagai berikut: Gambar 1. Model Penelitian.

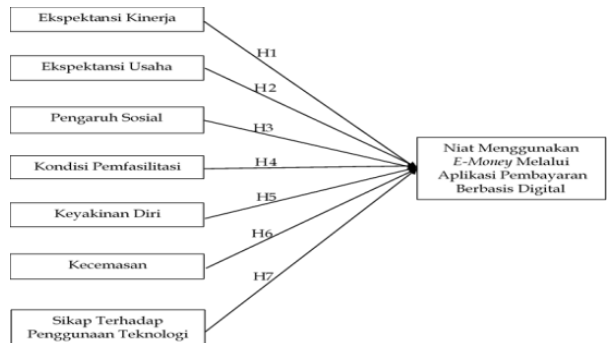

Sumber: Data penelitian, 2020

\section{METODE PENELITIAN}

Penelitian ini menggunakan pendekatan kuantitatif dengan jenis data primer. Pengumpulan data dilakukan dengan mendistribusikan kuesioner online selama kurang lebih satu bulan melalui google docs. Teknik purposive sampling yang digunakan di dalam penelitian ini untuk menentukan kriteria responden. Sampel yang digunakan dalam penelitian ini adalah 290 pengguna $e$-money di Kota Batam yang bertransaksi melalui aplikasi pembayaran berbasis digital selama lima bulan terakhir (April 2020 s.d Agustus 2020).

Total kuesioner yang didistribusikan melalui google docs sebanyak 350. Sebelum responden melakukan pengisian kuesioner, peneliti memastikan bahwa mereka merupakan pengguna $e$-money. Total responden yang memiliki e-money adalah sebanyak 304 responden. Namun, hanya 290 responden yang termasuk dalam kriteria dikarenakan mereka memiliki e-money dan bertransaksi melalui aplikasi pembayaran berbasis digital selama lima bulan terakhir. 
Instrumen penelitian diadaptasi dari penelitian terdahulu. Ekspektasi kinerja, ekspektasi usaha, pengaruh sosial, kondisi pemfasilitasi, dan minat pengguna diadaptasi dari Venkatesh et al., (2012), Kecemasan dan sikap pengguna pengguna teknologi diadaptasi dari Rana et al., (2017). Efikasi diri diadaptasi dari Shaw (2014) dan Venkatesh et al., (2003). Instrumen penelitian menggunakan lima skala likert ( sangat setuju $=5$ s.d sangat tidak setuju =1).

Pengujian instrument penelitian menggunakan uji validitas dan uji reliabilitas. Uji validitas menggunakan nilai Average Variance Extracted (AVE), jika nilai AVE >0,5, maka instrumen penelitian dinyatakan valid. Sedangkan uji reliabilitas menggunakan nilai Cronbach's alpha, jika nilai alpha $>0,6$, maka instrumen dinyatakan reliabel (Hair et al., 2010). Peneliti menggunakan SEM Partial Least Square (PLS) dengan alat analisis WrapPLS 7.0 sebagai metode analisis statistik.

\section{HASIL DAN PEMBAHASAN}

Responden dalam penelitian ini didominasi oleh perempuan sebanyak 213 orang (73\%), dan laki-laki sebanyak 77 orang (27\%). Selanjutnya, umur responden didominasi oleh rentang umur 20-30 tahun sebanyak 190 orang (65\%). Lalu, responden dengan rentang umur dibawah 20 tahun sebanyak 69 orang (24\%), umur 30-40 tahun sebanyak 19 orang $(7 \%)$, dan umur diatas 40 tahun sebanyak 12 orang (4 orang). Selanjutnya, pekerjaan responden didominasi oleh pelajar/mahasiswa sebanyak 172 orang (59\%) dan karyawan swasta sebanyak 97 orang (33\%). Responden lainnya bekerja sebagai wiraswasta sebanyak 8 orang (3\%) dan PNS sebanyak 5 orang (2\%). Sementara itu, pendapatan tertinggi didominasi oleh responden yang memiliki pendapatan di rentang
Rp4.000.000 - Rp5.000.000 sebanyak 133 orang (46\%); Rp2.000.000 - Rp3.000.000 sebanyak 73 orang (25\%); dan Rp1.000.000 - Rp2.000.000 sebanyak 58 orang $(20 \%)$.

Tabel 2: Data Demografi Responden

\begin{tabular}{|c|c|c|}
\hline Kategori & Jumlah & Persentase (\%) \\
\hline \multicolumn{3}{|l|}{ Jenis Kelamin } \\
\hline Laki-laki & 77 & 27 \\
\hline Perempuan & 213 & 73 \\
\hline \multicolumn{3}{|l|}{ Umur (tahun) } \\
\hline$<20$ & 69 & 24 \\
\hline $20-30$ & 190 & 65 \\
\hline $30-40$ & 19 & 7 \\
\hline$>40$ & 12 & 4 \\
\hline \multicolumn{3}{|l|}{ Pekerjaan } \\
\hline Karyawan Swasta & 97 & 33 \\
\hline PNS & 5 & 2 \\
\hline Pelajar/Mahasiswa & 172 & 59 \\
\hline Tidak/Belum Bekerja & 8 & 3 \\
\hline Wiraswasta & 8 & 3 \\
\hline \multicolumn{3}{|l|}{ Pendapatan } \\
\hline$>10$ juta & 9 & 3 \\
\hline $1-2$ juta & 58 & 20 \\
\hline $2-3$ juta & 73 & 25 \\
\hline $4-5$ juta & 133 & 46 \\
\hline 6-7 juta & 12 & 4 \\
\hline $8-10$ juta & 3 & 1 \\
\hline Tidak Menjawab & 2 & 1 \\
\hline
\end{tabular}

Sumber: Data Penelitian, 2020

Berdasarkan hasil pengujian, nilai Tenenhaus GoF sebesar 0,746 dan nilai ARS (Average R-Squared) sebesar 0,648. Hal ini menunjukkan bahwa model penelitian sudah memenuhi goodness of fit yaitu sebesar $64,8 \%$. Dengan demikian, konstruk dari masing-masing variabel penelitian dapat diuji lebih lanjut dengan melakukan analisis validitas dan reliabilitas.

Selanjutnya, hasil pengujian menunjukkan bahwa instrumen penelitian dinyatakan valid. Hal ini ditunjukkan dengan nilai AVE untuk masing-masing konstruk adalah >0,5 (Hair et al., 2010). Selain itu, instrumen penelitian juga dinyatakan reliabel. Masing-masing konstruk penelitian menunjukkan nilai composite reliability $(\mathrm{CR})$ sebesar $>0,8$ dan cronbach's alpha (CA) sebesar $>0,7$ (Hair et al., 2010).

Tabel 3: Validitas dan Reliabilitas Konstruk AVE $\quad$ CR $\quad$ CA 


\begin{tabular}{|c|c|c|c|}
\hline \multicolumn{4}{|c|}{$\begin{array}{l}\text { Jurnal Ifmiah Ekomom } \\
\text { Vol. 18. No.1,Maret } 2021: 47-56 \\
\text { EISSN : } 2442-9813 \\
\text { ISSN : } 1829-9822\end{array}$} \\
\hline $\begin{array}{l}\text { Ekspektasi Kinerja } \\
\text { (EK) }\end{array}$ & 0,860 & 0,961 & 0,945 \\
\hline $\begin{array}{l}\text { Ekspektasi } \\
\text { (EU) }\end{array}$ & 0,859 & 0,961 & 0,945 \\
\hline $\begin{array}{l}\text { Pengaruh } \\
\text { (PS) }\end{array}$ & 0,743 & 0,919 & 0,878 \\
\hline $\begin{array}{l}\text { Kondisi } \\
\text { Pemfasilitasi (KP) }\end{array}$ & 0,775 & 0,932 & 0,902 \\
\hline Efikasi Diri (ED) & 0,570 & 0,841 & 0,747 \\
\hline Kecemasan (KC) & 0,783 & 0,935 & 0,908 \\
\hline Sikap (S) & 0,884 & 0,958 & 0,934 \\
\hline Niat Pengguna (NP) & 0,830 & 0,936 & 0,897 \\
\hline
\end{tabular}

Sumber: Data Penelitian, 2020

Pengujian hipotesis pada penelitian ini menggunakan tingkat signifikansi sebesar 5\%. Jika nilai $p$ value dibawah 5\%, maka hipotesis dinyatakan signifikan. Berikut hasil dari pengujian hipotesis masing-masing konstruk:

Tabel 4: Hasil Pengujian Hipotesis

\begin{tabular}{ccccc}
\hline Hipotesis & Konstruk & P Value & $\begin{array}{c}\text { Path } \\
\text { Coefficient }\end{array}$ & Keterangan \\
\hline H1 & EK $\rightarrow$ NP & $<0,001$ & 0,222 & Terdukung \\
\hline H2 & EU $\rightarrow$ NP & 0,031 & 0,108 & Terdukung \\
\hline H3 & PS $\rightarrow$ NP & $<0,001$ & 0,183 & Terdukung \\
\hline H4 & KP $\rightarrow$ NP & 0,041 & 0,101 & Terdukung \\
\hline H5 & ED $\rightarrow$ NP & 0,114 & 0,070 & Tidak Terdukung \\
\hline H6 & KC $\rightarrow$ NP & 0,260 & 0,038 & Tidak Terdukung \\
\hline H7 & S $\rightarrow$ NP & $<0,001$ & 0,443 & Terdukung \\
\hline
\end{tabular}

Hasil pengujian hipotesis pertama menunjukkan bahwa terdapat pengaruh positif dan signifikan antara ekspektasi kinerja dengan niat menggunakan e-money melalui aplikasi pembayaran berbasis digital. Dibuktikan dengan nilai $p$ value $=<0,001$ dan path coefficient $(0,222)$ menujukkan arah positif.

Hasil pengujian hipotesis pertama mendukung hasil penelitian Gunawan, Sinaga, \& WP (2019), yaitu ekspektasi kinerja berpengaruh positif pada minat penggunaan teknologi $e$ money. Selain itu, ekspektasi kinerja juga berpengaruh pada minat penggunaan sistem pembayaran digital (Sivathanu, 2019). Dengan demikian, sistem e-money yang dilakukan melalui pembayaran berbasis digital memberikan kemudahan dan meningkatkan kinerja kepada konsumen.

Hasil pengujian hipotesis kedua menunjukkan bahwa ekspektasi usaha berpengaruh positif dan terbukti signifikan terhadap niat menggunakan $e$ - money. Nilai $p$ value $=0,031$ dan path coefficient $(0,108)$ menujukkan arah positif. Semakin mudah menggunakan teknologi, maka semakin tinggi niat individu untuk meggunakan teknologi tersebut. Hasil pengujian hipotesis kedua mendukung hasil penelitian Gupta \& Arora (2020); Khatimah \& Halim (2014); Baishya \& Samalia (2020), yang menyatakan bahwa ekspektasi usaha berpengaruh positif pada penggunaan pembayaran berbasis digital melalui layanan seluler. Hal ini menunjukkan bahwa individu memiliki tingkat kemanfaatan yang tinggi ketika menggunakan e-money melalui aplikasi pembayaran berbasis digital.

Hasil pengujian hipotesis ketiga menunjukkan pengaruh sosial berpengaruh positif dan signifikan terhadap niat menggunakan e-money. Nilai $p$ value $=<0,001$ dan path coefficient menujukkan arah positif. Semakin tinggi pengaruh sosial kepada individu individu untuk menggunakan suatu teknologi, maka semakin tinggi juga niat individu untuk menggunakan teknologi tersebut.

Hasil pengujian hipotesis ketiga mendukung hasil penelitian Junadi \& Sfenrianto (2015) dan Al-Okaily et al., (2020). Kesediaan individu untuk menggunakan suatu sistem dipengaruhi oleh opini orang-orang disekitarnya. Hasil penelitian menunjukkan bahwa individu dengan pengaruh sosial yang tinggi memiliki niat yang tinggi untuk menggunakan e-money melalui aplikasi pembayaran berbasis digital.

Hasil pengujian hipotesis keempat menunjukkan bahwa kondisi pemfasilitasi berpengaruh positif dan signifikan terhadap niat menggunakan $e$-money. Hal ini dibuktikan dengan nilai $p$ value $=$ 0,041 dan path coefficient menujukkan arah positif. Semakin tinggi fasilitas yang tersedia, semakin tinggi pula niat individu untuk melakukan suatu perilaku tertentu.

Hasil pengujian hipotesis keempat 
mendukung hasil penelitian Chawla \& Joshi (2019) yang menunjukkan bahwa kondisi pemfasilitasi berpengaruh positif terhadap penggunaan teknologi online melalui dompet seluler. Selain itu, penelitian Odoom \& Kosiba (2020) menunjukkan bahwa kondisi pemfasilitasi juga berpengaruh positif pada niat berkelanjutan perusahaan mikro untuk menggunakan pembayaran digital melalui seluler.

Hasil pengujian hipotesis kelima dan keenam tidak menunjukkan keterdukungan. Efikasi diri dan kecemasan tidak berpengaruh dan tidak signifikan terhadap niat menggunakan $e$ money $(p$ value $=0,114 ; p$ value $=$ 0,260). Efikasi diri tidak menjadikan seseorang menjadi lebih ahli dalam penggunaan teknologi. Penggunaan $e$ money melalui aplikasi pembayaran berbasis digital bukan untuk mengasah kemampuan teknologi seseorang, melainkan untuk mempermudah suatu transaksi.

Selain itu, kecemasan yang dimiliki individu cenderung rendah ketika menggunakan e-money melalui aplikasi pembayaran berbasis digital. Di Indonesia, e-money yang terkoneksi dengan aplikasi pembayaran berbasis digital memiliki $Q R$ Code dan layanan keamanan seperti finger print, kode transaksi, dan jaminan kerahasiaan data. Faktor-faktor ini memicu individu untuk mempercayai aplikasi pembayaran yang digunakan, sehingga rasa kecemasan tidak menjadi faktor pendukung dalam penggunaan e-money melalui aplikasi tersebut.

Hasil pengujian hipotesis kelima berbeda dengan hasil penelitian Al-Saedi et al., (2020); dan Boonsiritomachai \& Pitchayadejanant (2017); yang menunjukkan bahwa efikasi diri berpengaruh positif dan signifikan pada penggunaan pembayaran mobile secara digital.

Hipotesis keenam menunjukkan hasil yang tidak signifikan, yakni kecemasan berpengaruh negatif pada niat menggunakan e-money melalui pembayaran berbasis digital. Hal ini sejalan dengan hasil penelitian Venkatesh et al., (2003) dan Verkijika (2020) yang menunjukkan tidak adanya signifikansi antara kecemasan dan niat untuk menggunakan suatu teknologi. Kecemasan hanya sebuah emosi atau perasaan yang tidak berhubungan dengan penerimaan suatu aplikasi sistem pembayaran berbasis digital. Semakin meningkatnya popularitas penggunaan $e$ money melalui aplikasi pembayaran berbasis digital, maka tingkat kecemasan untuk menggunakan aplikasi tersebut akan semakin berkurang.

Hasil pengujian hipotesis ketujuh menunjukkan bahwa sikap terhadap penggunaan teknologi berpengaruh positif dan signifikan terhadap niat menggunakan $e$-money. Nilai $p$ value $=<0,001$ dan path coefficient menujukkan arah positif. Semakin tinggi sikap positif yang ditunjukkan oleh suatu individu terhadap teknologi, maka semakin tinggi niat untuk menggunakan teknologi tersebut. Dengan demikian, individu memiliki persepsi positif pada penggunaan e-money. Hasil pengujian hipotesis ketujuh mendukung hasil penelitian Patil et al., (2020) yang menunjukkan bahwa sikap berpengaruh positif terhadap pembayaran berbasis digital.

\section{KESIMPULAN DAN SARAN}

Tujuan penelitian ini adalah untuk menganalisis faktor-faktor yang memengaruhi niat penggunaan e-money melalui aplikasi pembayaran berbasis digital menggunakan model UTAUT. Peneliti menggunakan tujuh konstruk dari model UTAUT untuk menganalisis faktor terkuat yang memengaruhi individu dalam menggunakan e-money. Lima diantara konstruk yang diajukan memiliki tingkat signikansi paling tinggi dalam memengaruhi minat individu terhadap 


\section{Jurnal Ilmiah Ekonomi dan Bisnis}

Vol. 18. No.1,Maret $2021: 47-56$

EISSN : $2442-9813$

ISSN : $1829-9822$

penggunaan e-money, khususnya di Kota Batam. Diantaranya yaitu; ekspektasi kinerja, pengaruh sosial, dan sikap terhadap penggunaan teknologi. Kemudian, faktor lainnya adalah ekspektasi usaha dan fasilitas pemfasilitasi. Konstruk efikasi diri dan kecemasan menjadi faktor yang tidak berpengaruh terhadap niat individu untuk menggunakan $e$-money.

Keterbatasan penelitian ini adalah terhambatnya proses interview secara mendalam terhadap hasil kuesioner yang diisi oleh responden. Penyebaran kuesioner hanya berfokus di Kota Batam karena tingkat penggunaan $e$-money masih rendah. Penelitian selanjutnya dapat menganalisis lebih mendalam mengenai fenomena atas ketidakterdukungan hipotesis pada konstruk efikasi diri dan kecemasan. Analisis lanjut juga dapat memperluas sampel penelitian dan menambah konstruk lainnya pada model UTAUT 2.

\section{DAFTAR PUSTAKA}

Agusta, J., Adi, W., Muksit, H., Hutabarat, K., \& Hanzdima, A. (2018, March 5). Mobile Payments In Indonesia: Race to Big Data Domination. Diakses dari MDI Ventures by Telkom Indonesia:

https://mdi.vc/whitepaper/detail/3 /Mobile\%20Payments\%20In\%20 Indonesia\%3A\%20Race $\% 20$ to $\%$ 20Big\%20Data\%20Domination

Al-Okaily, M., Lutfi, A., Alsaad, A., Taamneh, A., \& Alsyouf, A. (2020). The Determinants of Digital Payment Systems' Acceptance under Cultural Orientation Differences: The Case of Uncertainty Avoidance. Technology in Society, 63, 101367.

doi:https://doi.org/10.1016/j.techs oc. 2020.101367
Al-Saedi, K., Al-Emran, M., Ramayah, T., \& Abusham, E. (2020). Developing a general extended UTAUT model for M-payment adoption. Technology in Society, 62 , 101293. doi:https://doi.org/10.1016/j.techso c. 2020.101293

Baishya, K., \& Samalia, H. V. (2020). Extending unified theory of acceptance and use of technology with perceived monetary value for smartphone adoption at the bottom of the pyramid. International Journal of Information Management, $\quad 51, \quad 102036$. doi:https://doi.org/10.1016/j.ijinfo mgt.2019.11.004

Boonsiritomachai, W., \& Pitchayadejanant, K. (2017). Determinants affecting mobile banking adoption by generation $\mathrm{Y}$ based on the Unified Theory of Acceptance and Use of Technology Model modified by the Technology Acceptance Model concept. Kasetsart Journal of Social Sciences, $x x x, \quad 1-10$. doi:https://doi.org/10.1016/j.kjss.2 017.10 .005

BPS Indonesia. (2019). Statistik ECommerce 2019. Badan Pusat Statistik Indonesia.

Chawla, D., \& Joshi, H. (2019). Consumer attitude and intention to adopt mobile wallet in India - An empirical study. International Journal of Bank Marketing, 37(7), 1590-1618. doi:10.1108/IJBM-092018-0256

Dehghan, F., \& Haghighi, A. (2015). Emoney regulation for consumer protection. International Journal of Law and Management, 610-620. doi:10.1108/IJLMA-06-2014-0042

Devita, V. D. (2019, August 12). Siapa Aplikasi E-wallet dengan Pengguna Terbanyak di Indonesia? Diambil kembali dari Iprice: 
https://iprice.co.id/trend/insights/ e-wallet-terbaik-di-indonesia/

Gunawan, H., Sinaga, B. L., \& WP, S. P. (2019). Assessment of the Readiness of Micro, Small and Medium Enterprises in Using $E$ money Using the Unified Theory of Acceptance and Use of Technology (UTAUT) Method. Procedia Computer Science, 161, 316-323.

doi:https://doi.org/10.1016/j.proc s.2019.11.129

Gupta, K., \& Arora, N. (2020). Investigating consumer intention to accept mobile payment systems through unified theory of acceptance model. South Asian Journal of Business Studies, 9(1), 88-114. doi:10.1108/SAJBS-032019-0037

Gurkaynak, G., \& Yilmaz, I. (2015, June). Regulating payment services and electronic money: A comparative regulatory approach with a specific focus on Turkish legislation. Computer Law \& Security Review, 31(3), 401-411. doi:https://doi.org/10.1016/j.clsr. 2015.03.009

Hair Jr, J., Black, W. C., Babin, B. J., \& Anderson, R. E. (2010). Multivariate Data Analysis: A Global Perspective. (7, Penyunt.) Prentice Hall.

Hartono, J. (2008). Sistem Informasi Keperilakuan. Andi Publisher.

Junadi, \& Sfenrianto. (2015). Model of Factors Influencing Consumer's Intention To Use E-Payment System in Indonesia. Procedia Computer Science, 59, 214 - 220. doi:10.1016/j.procs.2015.07.557

Keong, M. L., Ramayah, T., Kurnia, S., \& Chiun, L. M. (2012). Explaining intention to use an enterprise resource planning (ERP) system: an extension of the UTAUT model. Business Strategy Series,
13(4),

173

ISSN : $1829-9822$

doi:https://doi.org/10.1108/175156 31211246249

Khatimah, H., \& Halim, F. (2014, July). Consumers' Intention to Use $e$ money in Indonesia Based on Unified Theory of Acceptance and Use of Technology (UTAUT). American-Eurasian Journal of Sustainable Agriculture, 8(12), 3440. Diambil kembali dari http://repo.uum.edu.my/id/eprint/1 2776

Lynch, D. C., \& Lundquist, L. (1996). Digital Money The New Era Of Internet Commerce (1st ed.). New York, United States: John Wiley and Sons Ltd.

Nag, A. K., \& Gilitwala, B. (2019, November). E-Wallet- Factors Affecting Its Intention to Use. International Journal of Recent Technology and Engineering (IJRTE), 8(4). doi:10.35940/ijrte.D6756.118419

Octabriyantiningtyas, D., Suryani, E., \& Jatmiko, A. R. (2019). Modeling Customer Satisfaction with the Service Quality of E-money in Increasing Profit of PT. Telekomunikasi Indonesia. Procedia Computer Science, 161, 943-950. doi:10.1016/j.procs.2019.11.203

Odoom, R., \& Kosiba, J. P. (2020). Mobile money usage and continuance intention among micro enterprises in an emerging market - the mediating role of agent credibility. Journal of Systems and Information Technology, 22(1), 97-117. doi:10.1108/JSIT-032019-0062

Patil, P., Tamilmani, K., Rana, N. P., \& Raghavan, V. (2020). Understanding consumer adoption of mobile payment in India: Extending Meta-UTAUT model with personal innovativeness, 
Jurnal Ilmiah Ekonomi dan Bísnis

Vol. 18. No.1,Maret $2021: 47-56$

EISSN : $2442-9813$

ISSN : $1829-9822$

anxiety, trust, and grievance redressal. International Journal of Information Management, 54, 102144.

doi:https://doi.org/10.1016/j.ijinf omgt.2020.102144

PWC Research. (2019). It's time for a consumer-centred metric: introducing 'return on experience'. Diambil kembali dari PWC Global: https://www.pwc.com/ee/et/publi cations/pub/Consumer-InsightSurvey-2019-report.pdf

Rana, N. P., Dwivedi, Y. K., Lal, B., Williams, M. D., \& Clement, M. (2017). Citizens' adoption of an electronic government system: towards a unified view. Inf Syst Front, 19, 549-568. doi:10.1007/s10796-015-9613-y

Shaw, N. (2014). The mediating influence of trust in the adoption of the mobile wallet. Retailing and Consumer Services, 21, 449-459. doi:http://dx.doi.org/10.1016/j.jre tconser.2014.03.008

Sivathanu, B. (2019). Adoption of digital payment systems in the era of demonetization in India. Journal of Science and Technology Policy Management, 10(1), 143-171. doi:10.1108/JSTPM-07-20170033

Tak, P., \& Panwar, S. (2017). Using UTAUT 2 Model to Predict Mobile App based shopping: Evidences from India. Journal of Indian Business Research, 9(3), 248-264. doi:https://doi.org/10.1108/JIBR11-2016-0132

Taufan, A., \& Yuwono, R. T. (2019, July). Analysis of Factors That Affect Intention to Use e-Wallet through the Technology Acceptance Model Approach (Case Study: GO-PAY). International Journal of Science and Research (IJSR), 8(7). doi:10.21275/ART2020219

Ting, H., Yacob, Y., Liew, L., \& Lau, W. M. (2016). Intention to Use Mobile Payment System: A Case of Developing Market by Ethnicity. Procedia - Social and Behavioral Sciences, 224, $368-375$. doi:10.1016/j.sbspro.2016.05.390

Venkatesh, V., Morris, M. G., Davis, G. B., \& Davis, F. D. (2003, Sept). User Acceptance of Information Technology: Toward a Unified View. MIS Quarterly, 27(3), 425478. doi:10.2307/30036540

Venkatesh, V., Thong, J. Y., \& Xu, X. (2012, March). Consumer Acceptance and Use of Information Technology: Extending the Unified Theory of Acceptance and Use of Technology. MIS Quarterly, 36(1), 157-178. doi:10.2307/41410412

Verkijika, S. F. (2020). An affective response model for understanding the acceptance of mobile payment systems. Electronic Commerce Research and Applications, 39, 100905.

doi:https://doi.org/10.1016/j.elerap .2019.100905

Verma, S., Chaurasia, S. S., \& Bhattacharyya, S. S. (2020). The effect of government regulations on continuance intention of instore proximity mobile payment services. International Journal of Bank Marketing, 38(1), 34-62. doi:10.1108/IJBM-10-2018-0279

$\mathrm{Yu}$, C.-S. (2014, June). Consumer Switching Behavior From Online Banking To Mobile Banking. International Journal of Cyber Society and Education, 7(1), 1-28. doi:10.7903/ijcse.1108. 